
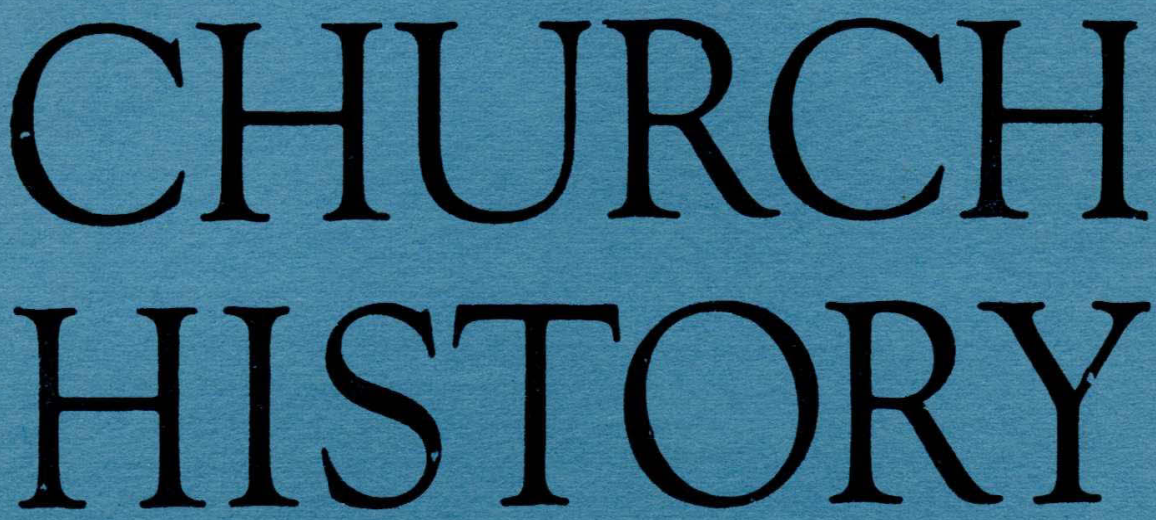

DECEMBER, 1949

The Word of God in the Westminster Assembly William Haller

Hugo of Saint-Victor as a Moral Allegorist Ford Lewis Battles

Thirty Years of Calvin Study: Addendum

John T. McNeill

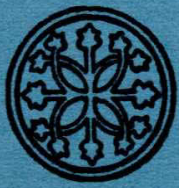

Published by 
FOUNDED BY PHILIP SCHAFF, 1888: REORGANIZED 1906: INCORPORATED BY ACT OF THE LEGISLATURE OF NEW YORK, 1916

\title{
OFFICERS FOR 1949
}

MASSEY H. SHEPHERD President

JaMES HASTINGS Nichols Vice-President

RAYMOND W. ALBRIGHT Secretary

M. M. DEEMS Assistant Secretary

ROBERT Hastings Nichols Treasurer

Mrs. Robert Hastings NICHOLS Treasurer pro tem MatTheW SpINKa Chairman of the Editorial Board

\section{OTHER MEMBERS OF THE COUNCIL}
HAROLD S. BENDER
SANDFORD Fleming
PERCy V. NORWOOD
SIDNEy E. MEAd
KenNeth S. Latouretre
ERNEST G. SchWIEBERT
Ray C. Petry
CARL E. SchNeIDER

WINTHROP S. HUDSON

\author{
EDITORIAL BOARD OF CHURCH HISTORY \\ Matthew SpInka, Chairman \\ WINTHROP S. HUDSON \\ RAY C. PETRY \\ James Hastings Nichols \\ Robert Hastings Nichols, ex officio \\ Publication Office, Berne, Indiana
}

Executive and Edtorial Office, 55 Elizabeth St, Hartford 5, ConN.

Church History is a quarterly journal published in March, June, September, December by the American Society of Church History. The subscription price is three dollars per year. The price of single copies is seventy-five cents. To foreign countries, twenty-five cents a year should be added. Subscriptions should be sent to Professor Matthew Spinka, 55 Elizabeth Street, Hartiord 5, Conn., or to Professor Robert Hastings Nichols, 21 Claremont Ave., New York 27, N. Y. Remittances should be made to the order of American Society of Church History.

All communications regarding contributions, book reviews, and all other matters of editorial nature should be sent to Professor Matthew Spinka, 55 Elizabeth St., Hartford 5, Conn.

Claims for missing numbers and changes of address should be acidressed to Prof. R. H. Nichols, 21 Claremont Ave., New York 27, N. Y.

Entered as second class matter March 9, 1934, at the post office at Berne, Ind., under the Acts of March 3, 1879. 


\title{
CHURCH \\ HISTORY
}

\author{
Edited by \\ Matthew Spinka \\ Winthrop S. Hudson \\ Ray C. Petry \\ James Hastings Nichols \\ Robert Hastings Nichols
}

\section{Volume XVIII \\ 1949}

\section{Published by \\ THE AMERICAN SOCIETY OF CHURCH HISTORY}




\section{TABLE OF CONTENTS}

\section{ARTICLES}

Pages

Battles, Ford Lewis, Hugo of Saint-Victor as a Moral Allegoriet....220-240 Downey, G., Paganism and Christianity in Procopius 89-102 Eller, Meredith F., The Retractationes of Saint Augustine ............172-183 Grimm, Harold J., Lorenzo Valla's Christianity ............................ 75-88 Haller, William, The Word of God in the Westminster Assembly..199-219 Hudson, Winthrop S., Puritanism and the Spirit of Capitalism.... 3-17 McNeill, John T., The Democratic Element in Calvin's Thought....153-171 McNeill, John T., Thirty Years of Calvin Study : Addendum ......... 241 Mullett, Charles F., Toleration and Persecution in England, $1660-1689$

\section{Minutes of the Society}

Minutes of the Sixty-fifth Consecutive Meeting of the American Society of Church History, December 29-30, 1948

Minutes of the Sixty-sixth Consecutive Meeting of the American Society of Church History, April 7-9, 1949 $103-104$

Minutes of the Meeting of the Council of the Society, December 29, 1948

Minutes of the Meeting of the Council of the Society, April 8, 1949 105-106

\section{MeMbers of The Society}

List of Members of the American Society of Church History $129-149$ 


\section{BOOK REVIEWS}

Alföldi, Andrew, The Conversion of Constantine and Pagan Rome. 244-245

Ames, Russell, Citizen Thomas More and his Utopia 249-250

Armstrong. Maurice W., The Great Awakening in Nova Scotia, 1766-1809 120-121

Bartoš, G. M., Knihy a Zápasy

Bell, G. K. A., ed., Documents of Christian Unity, Third Series, 1930-1948 118-119

Benz, Ernst, Emanuel Swedenborg 252-253

Benz, Ernst, Wittenberg and Byzanz 187-188

Berry, Virginia G., ed., Odo of Deuil de Profectione Ludovici VII in Orientem 57-58

Bower, W. C., and Hayward, P. R., Protestantism Faces its Educational Task Together 192.193

Braden, Charles Samuel, These Also Believe 259.260

Brunner, Emil, Christianity and Civilisation 242-243

Calvin, John, Instruction in Faith (1537). 247-248

Garlson, Edgar M., The Reinterpretation of Luther 110-112

Cassirer, Ernst and others, eds., The Renaissance Philosophy of Man 185-187

Cave, C. J. P., Roof Bosses in Mediaeval Churches 245.246

Chase, Mary Ellen., Jonathan Fisher, Maine Parson, 1768-1847.

Chureh, Leslie F., The Earliest Methodist People

Chureh, Leslie F., Contributi allaStoria del Concilio Trents e della Contrari forma

Cross, S. H., Mediaeval Russian Churches

Davies, Horton, The Worship of the English Puritans 250-251

Dalbert, Peter, Die Reformation in den italienischen Talschaften Graubündens nach dem Briefwechsel Bullingers

Davis, D. R., Reinhold Niebuhr: The Prophet from America 68- 69

Davis, Georgene W., The Inquisition at Albi, 1299-1300 56- 57

de Dubac, Henri, S. J., The Un-Marxian Socialist... A Study of Proudhon .... $59-60$ Drorník, Francis, The Photian Scism, History and Legend 184-185

Ebeling, Gerhard, Evangelische Evangelienauslegung

Edwards, George $\mathrm{N}$, A History of the Independent or Congregational Church of Charleston, South Carolina

Eisenach, George J., Pietism and the Russian Germans in the $U$. S. ............. 256

Elson, James Hinsdale, Iohn Hales of Eton ........................................ 114-115

Hill, J. W. F., Medieval Lincoln 108-109

Hughes, Philip, A Popular Bistory of the Catholic Church

Hugh-Jones, E. M., Woodrow Wilson and America Liberalism 


\section{BOOK REVIEWS}

Hughley, J. Neal, Trends in Protestant Social Idealism

Iremonger, F. A., William Temple, Arohbishop of Canterbury: His Life. and Letters

Janelle, Pierre, The Catholic Reformation

Kennedy, Hugh A. B., Mrs. Eddy; Her Life, Her Work and Her Place in History

Knox, T. M., tr., Georg Wilhelm Friedrich Hegel: Early Theological Writings $115 \cdot 117$

Lamm, Martin, Emanuel Swedenborg

Latourette, Kenneth Scott, The Emergence of a World Christian Community

Lehmann, KarI, Thomas Jefferson 254-256

Loisy, Alfred, The Birth of the Christian Religion

Loomis, C. Grant, White Magic

McKeon, Charles, A Study of the "Summa Philosophiae" of the PseudoGrosseteste

May, Henry F., Protestant Churches and Industrial America

Morris, William Dale, The Christian Origins of Social Revolt 251-252

Murdock, Kenneth B., Literature and Theology in Colonial New England 254

Osborn, Ronald C., Ely Vaughan Zollars $67-68$

O'Neill, J. M., Religion and Education Under the Constitution

Petry, Ray C., ed., No Uncertain Sound $107-108$

Purvis, J. \$., Tudor Parish Documents of the Diooese of York

Roth, Cecil, The House of Nasi: The Duke of Naxos

$112-113$

Ruggles, Eleanor, Journey into Faith

Savage, Theodore Fisk, The Presbyterian Church in New Fork City

Schenk, Wilhelm, The Concern for Social Justice in the Puritan Revolution 190-192

Seesholtz, Anne, Saint Elizabeth, Her Brother's Keeper ................................ 108

Smith, H. Maynard, Henry VIII and Reformation

Thomas, Sister M. Evangeline, Footprints on the Frontier

Thomte, Reidar, Kierkegaard's Philosophy of Religion

Tolles, F. B., Meeting House and Counting House: The Quaker Merchants of Colonial Philadelphia, 1682-1763

Torpey, William George, Judicial Doctrines on Religious Rights in America

Toulmin, Harry, The Western Country in 1793: Report on Kentucky and Virginia

Troeltsch, Ernst, The Social Teaching of the Christian Churohes

Wilson, P. W., General Evangeline Booth of the Salvation Army 


\section{CHURCH HISTORY}

EDITORIAL BOARD

Matthew Sptnka, Chairman

WINTHROP S. HUDSON

Ray C. PETry

JaMES Hastings Nichols

ROBERT HASTINGS Nichous, ex officio

Vol. XVIII

December, 1949

No. 4

Contents of previous issues of CHURCH HISTORY may be found by consulting the International Index to Periodicals in your library.

\section{TABLE OF CONTENTS}

The Word of God in the Westminster Assembly William Haller

Hugo of Saint-Victor as a Moral Allegorist Ford Lewis Battles

Thirty Years of Calvin Study: Addendum

John T. McNeill

Book Reviews

Brunner, Emil: Christianity and Civilisation First Part: Foundations Albert C. Outler

Troestsch, ERnst: The Social Teaching of the Christian Churches C. G. Chakerian

Torrance, T. F.: The Doctrine of Grace in the Apostolic Fathers George Johnston

AlFöLdi, ANDREw : The Conversion of Constantine and Pagan Rome Mervin M. Deems

CAve, C. J. P.: Roof Bosses in Mediaeval Churches An Aspect of Gothic Sculpture E. R. Hardy, Jr. 


\section{CONTENTS}

Loomis, C. G.: White Magic: An Introduction to the Folklore of Christian Legend Raymond W. Albright

Bartoš, F. W.: Knihy A. Zápasy Matthew Spinka

Calvin, John. (Tr. and ed., Paul T. Fuhrmann): Instruction in Faith (1537) Edwin Lewis

Janelle, Pierre: The Catholic Reformation .... Winthrop S. Hudson

Ames, RussedL: Thomas More and His Utopia .... Charles F. Mullett

Davies, Horton: The Worship of the English Puritans Babette M. Levy

Morris, W. D.: The Chritian Origins of Social Revolt James F. Maclear

Benz, ERnst: Emanuel Swedenborg, Naturforscher und Seher Howard D. Spoerl

Lamm, Martin : Emanuel Swedenborg: Ausgewählte Religiöse Schriften Howard D. Spoerl

Murdock, K. B.: Literature and Theology in Colonial Nerw England John W. Brush

Lehmann, Karl: Thomas Jefferson: American Humanist Preston Roberts

Eisenach, G. J.: Pietism and the Russian Germans in the United States Clark Harshfield

May, Henry F.: Protestant Churches and Industrial America Gaylord P. Albaugh

Braden, C. S.: These Also Believe Wm. C. Walzer

Savage, T. F.: The Presbyterian Church in New York City Robert H. Nichols

LAtourette, K. S.: The Emergence of a World Christian Community

H. E. Bernhard 